\title{
PROPAGATION OF Gardenia jasminoides ELLIS BY USING TISSUE CULTURE TECHNIQUES
}

(Received: 26 . 5 .2013)

\author{
By \\ A. M. S. Arafa, S. H. El-Hanafy, M.A. El-Shamy* and N. A. K. Namira* \\ Ornamental Horticulture Department, Faculty of Agriculture, Cairo University. \\ *Botanical Garden Research Department, Horticulture Research Institute, \\ Agriculture Research Center, Giza, Egypt.
}

\begin{abstract}
The experimental trial was consummated in the Plant Tissue Culture Laboratory at El-Zohria Botanical Garden, Horticulture Research Institute, Agriculture Research Center, Ministry of Agriculture from 2010 to 2012. The aim of this study was to reach a well defined protocol for in vitro propagation of Gardenia jasminoides Ellis plant. Shoot tips and auxiliary buds of G. jasminoides were surface sterilized with 30\% Clorox (®sodium hypochlorite as commercial bleach) for $25 \mathrm{~min}$ which gave the best results (100\% survival, $0.0 \%$ contamination and $(0.0 \%)$ mortality of shoot tips and auxiliary buds. Explants were cultured on MS medium supplemented with $4.0 \mathrm{mg} / \mathrm{l} \mathrm{NAA}$ for effective establishment . In the multiplication stage, $5.0 \mathrm{mg} / \mathrm{l} \mathrm{BA}$ was favoured for the number of shoots. For in vitro rooting, $5.0 \mathrm{mg} / \mathrm{l}$ IBA was more suitable to form roots on G.jasminoides. After one month in a rooting medium, gardenia plants were transplanted into pots containing peatmoss and covered by polyethylene sheets. After one month, the sheets were removed and left for two weeks under plastic house conditions where $100 \%$ of the plants survived.
\end{abstract}

Key words: gardenia, in vitro .micropropagation, shoot tips ,tissue culture.

\section{INTRODUCTION}

Gardenia is an indoor ornamental plant. The flower has an attractive appearance accompanied with very nice fragrance. The plant is a source for the pigment carotene. Propagation of Gardenia is a difficult task.

Minas (2007) demonstrated that Gardenia plants were taken to the laboratory, 10 apical growing shoots, $5 \mathrm{~cm}$ long, were removed from each plant and sterilised by soaking in $20 \%$ commercial bleach solution with a few drops of Tween 20 for $10 \mathrm{~min}$ and washed 3 times in distilled sterile water. This treatment was the most suitable for surface sterilization.

Shen (1990) reported that $G$. jasminoides was cultured on MS medium supplemented with 2 $\mathrm{mg} / \mathrm{l} \mathrm{BA}$ plus $0.1 \mathrm{mg} / \mathrm{l} \mathrm{IAA}$, then sub cultured on medium containing $3 \mathrm{mg} / \mathrm{l} \mathrm{BA}$ plus $0.05 \mathrm{mg} / \mathrm{l} \mathrm{IAA}$ at the establishment stage. Mir et al. (2010) demonstrated that BAP was the most effective cytokinin for the induction of shoots and synergistic effect between BAP and auxins was exhibited .It has a positive effect in the induction of shoots in G. gummifera. MS basal medium with
$1 \mathrm{mg} / \mathrm{l} \mathrm{BAP}$ and $0.5 \mathrm{mg} / \mathrm{lBA}$ yielded the highest number of shoots.

Mir et al. (2009) reported that explants of $G$. gummifera were cultured on MS medium with appropriate supplement of plant growth regulators. MS medium supplemented with BAP $2 \mathrm{mg} / \mathrm{l}$ and NAA $0.5 \mathrm{mg} / \mathrm{l}$ elicited the maximum number of shoots from nodal explants.

Pontikis (1983) found that rooting of $G$. jasminoides was achieved by transferring the shoots to a medium containing $1 \mathrm{mg} / \mathrm{l} \mathrm{IBA}$ and without BA. Dumanois et al. (1984) showed that rooting of Gardenia jasminoides occurred easily in 3 weeks in vitro in the presence of IAA $(1 \mathrm{mg} / \mathrm{l})$ and charcoal $(2 \mathrm{~g} / \mathrm{l})$ or in vivo by soaking the base of the shoot in the same auxin for $2 \mathrm{~h}$. George et al. (1993) found that efficient rooting of $\mathrm{G}$. jasminoides Ellis was achieved on MS medium supplemented with NAA at $5 \mathrm{mg} / \mathrm{l}$. Abdullah et al. (2003) demonstrated that the highest rooting percentage (up to $98 \%$ ) was obtained as a result of reducing the mineral salt concentration to half, 20 $\mathrm{g} / \mathrm{l}$ sucrose, $2 \mathrm{~g} / \mathrm{l}$ activated charcoal (AC) and 1 mg/l IAA. 
Economou and Spanoudaki (1986) found that microcuttings of gardenia harvested from cultures grown in a medium with $2 \mathrm{iP}$ or $2 \mathrm{iP}$ plus $\mathrm{GA}_{3}$ rooted readily in a peat:perlite mixture at $2: 1 \mathrm{v} / \mathrm{v}$.

The aim of this study was to investigate the best protocol for in vitro propagation of $G$. jasminoides Ellis for commercial production. Moreover, to determine and device simple and reliable methods for in vitro propagation through inducing growth. The current experiments were achieved on Gardenia jasminoides Ellis to investigate the effect of various media ingredients on shoot proliferation and rooting response of explants in vitro.

\section{MATERIALS AND METHODS}

This study was carried out in the Laboratory of Tissue Culture, Zohria Botantial Garden, Cairo, Egypt, Horticulture Research Institute, Agriculture Research Center, Ministry of Agriculture,Egypt.

The experiments were carried out during the period from (2010-2012), to study the most suitable protocol for micropropagation of $G$. jasminoides Ellis.

\subsection{Plant material}

The mother plants were grown under greenhouse conditions at Zohria Botanical Garden. Shoot tips and axillary buds were used as explants.

\subsection{Culture Room Conditions}

Cultures of $G$. jasminoides Ellis were placed in growth chambers under $25 \pm 2{ }^{\circ} \mathrm{C}$ and 16 -h photoperiod provided with white fluorescent light and 2000 lux.

\subsection{Culture Media}

Murashige and Skoog (MS) medium was used for explants of $G$. jasminoides Ellis. Media were solidified and supplemented with $7.0 \mathrm{~g} / \mathrm{l}$ agar. Sucrose at $30.0 \mathrm{~g} / \mathrm{l}$ was added as a source of carbohydrate. The $\mathrm{pH}$ of the medium was adjusted to 5.7. Twenty $\mathrm{ml}$ medium were poured in $150 \mathrm{ml}$ jars and sterilized by autoclaving under steam pressure $1.5 \mathrm{bar}$ at $121^{\circ} \mathrm{C}$ for $20 \mathrm{~min}$. Each treatment consisted of 3 jars. In each jar, three shoots were cultured separately.

\subsection{Experimental Treatments}

\subsubsection{Surface Sterilization of Explants}

Shoot tips of gardenia plants were excised from the mother plants, initially $1-2 \mathrm{~cm}$ in length, washed by soapy water for 5 minutes, followed by 1 hour under running tap water. The explants were surface sterilized by immersion in a Clorox (®sodium hypochlorite) solution as a commercial bleach at 20,30 and $40 \%$ containing 3-5 drops of Tween 20 for 15, 20, 25 and 30 minutes. Finally, they were washed 5 times with sterile distilled water. Each sterilized explant was cultured separately under sterile conditions in $100 \mathrm{ml}$ jar and each treatment consisted of three jars with three individual shoot in each jar.

\subsubsection{Establishment Stage}

Four treatments were initiated using NAA at $0.0,1.0,2.0$ and $4.0 \mathrm{mg} / \mathrm{l}$ for the establishment stage. In each treatment nine explants in three replicates were cultured for one month. Finally, the shoot length and the number of leaves were recorded.

\subsection{Multiplication Stage}

For the multiplication stage, seven treatments were initiated with $\mathrm{BA}$ at different concentrations $(0.0,0.5,1.0,2.0,3.0,4.0$ and $5.0 \mathrm{mg} / \mathrm{l} \mathrm{BA})$. This stage was repeated three times by subculturing on the same media treatments. At the end of the experiments, the collected data included the number of shoots, shoot length and the number of leaves.

\subsection{Rooting Stage}

For the rooting stage, four treatments were used with IBA at different concentrations (0.0, $1.0,3.0$ and $5.0 \mathrm{mg} / \mathrm{l} \mathrm{IBA})$. After one month, the number of leaves, shootlet length $(\mathrm{cm})$, the number of roots and root length $(\mathrm{cm})$ were scored.

\subsection{Acclimatization Stage}

Rooted plantlets were pricked out singly into $5 \mathrm{~cm}$ (in diameter) plastic pots filled with 1:0, 1:1 and 1:2(v/v) peatmoss and sand, respectively. The potted plantlets were kept in the green house. To maintain cultures at high humidity, pots were covered with clear transparent plastic sheets for one month. The plastic covers were then gradually removed to reduce humidity and to adapt plantlets to greenhouse conditions. At the end of the experiments, the collected data included shootlet length and number of leaves were recorded.

\subsection{Experimental Design and Statistical Analysis}

A factorial experiment in a complete randomized design was employed in all the experiments. Analysis of variance was used to show statistical differences between treatments using L.S.D at 5\% probability level (Snedecor and Cochran, 1989).

\section{RESULTS AND DISCUSSION}

3.1. Effect of Clorox concentrations and soaking periods on the survival percentage of surface sterilization for Gardenia explants

For surface sterilization of G. jasminoides, data in Table (1) revealed that the effect of Clorox 
was positive in survival percentage. The highest survival percentage was recorded at 30\% Clorox ®concentration.

For soaking period, the data indicated that increasing the time of immersing the explants the survival percentage increased. The highest percentage of survival explants was recorded with immersion for $25 \mathrm{~min}$.

The interaction between Clorox and time was significant with the highest percentage of survived explants (100), with $30 \%$ clorox for $25 \mathrm{~min}$.

The results obtained are in harmony with those obtained elsewhere when $70 \%$ alcohol (ethanol) and $30 \%$ Clorox were used alone (Hosni, 2001).

Table (1): Effect of different concentrations of Clorox and socking period on explants survival percentage of gardenia.

\begin{tabular}{|c|c|c|c|c|c|}
\hline $\begin{array}{c}\text { Min } \\
\text { Clorox }\end{array}$ & 15 & $\mathbf{2 0}$ & $\mathbf{2 5}$ & $\mathbf{3 0}$ & $\begin{array}{c}\text { Mean } \\
\text { (A) }\end{array}$ \\
\hline $\mathbf{2 0}$ & $\mathbf{4 4 . 4 4}$ & $\mathbf{5 5 . 5 5}$ & $\mathbf{5 5 . 5 5}$ & $\mathbf{6 6 . 6 7}$ & $\mathbf{5 5 . 5 5}$ \\
$\mathbf{3 0}$ & $\mathbf{5 5 . 5 5}$ & $\mathbf{6 6 . 6 7}$ & $\mathbf{1 0 0}$ & $\mathbf{7 7 . 7 8}$ & $\mathbf{7 5 . 0 0}$ \\
$\mathbf{4 0}$ & $\mathbf{6 6 . 7 6}$ & $\mathbf{6 6 . 6 7}$ & $\mathbf{5 5 . 5 5}$ & $\mathbf{4 4 . 4 4}$ & $\mathbf{5 8 . 3 4}$ \\
\hline Mean(B) & $\mathbf{5 5 . 5 5}$ & $\mathbf{6 2 . 9 7}$ & $\mathbf{7 0 . 3 7}$ & $\mathbf{6 2 . 9 6}$ & \\
\hline
\end{tabular}

L.S.D at 5\% $\quad A=11.44 \quad B=14.30 \quad A * B=22.87$

3.2. Effect of Clorox concentrations and soaking periods on mortality percentage of surface sterilization for Gardenia explants

The results demonstrated in Table (2) indicate that surface sterilization by Clorox was positively significant on mortality of Gardenia explant. This effect increased with the increase of clorox concentration. The best concentration was $20 \%$, which gave 0.0 mortality explants.

Concerning soaking period, data showed continuous additive increases in mortality percentage due to the increase in immersed soaking period. The highest percentage of mortality explants was recorded when the explants were soaked for $15 \mathrm{~min}$, which gave 3.70 percentage of mortality explants.

Table (2): Effect of Clorox concentrations and soaking periods on mortality percentage of surface sterilization for gardenia explants.

\begin{tabular}{|c|r|r|r|r|c|}
\hline $\begin{array}{l}\text { Min } \\
\text { Clorox }\end{array}$ & 15 & 20 & 25 & 30 & $\begin{array}{r}\text { Mean } \\
\text { (A) }\end{array}$ \\
\hline $\mathbf{2 0}$ & $\mathbf{0 . 0 0}$ & $\mathbf{0 . 0 0}$ & $\mathbf{0 . 0 0}$ & $\mathbf{0 . 0}$ & $\mathbf{0 . 0 0}$ \\
$\mathbf{3 0}$ & $\mathbf{0 . 0 0}$ & $\mathbf{1 1 . 1 1}$ & $\mathbf{0 . 0 0}$ & $\mathbf{2 2 . 2 2}$ & $\mathbf{8 . 3 3}$ \\
$\mathbf{4 0}$ & $\mathbf{1 1 . 1 1}$ & $\mathbf{3 3 . 3 3}$ & $\mathbf{3 3 . 3 3}$ & $\mathbf{5 5 . 5 5}$ & $\mathbf{3 3 . 3 3}$ \\
\hline Mean (B) & $\mathbf{3 . 7 0}$ & $\mathbf{1 4 . 8 1}$ & $\mathbf{1 1 . 1 1}$ & $\mathbf{2 5 . 9 4}$ & \\
\hline
\end{tabular}

L.S.D 5\% $A=9.82 \quad B=4.35 \quad A * B=18.72$
For the interaction between clorox concentrations and soaking periods, the use of clorox was lower at $20 \%$ clorox for different times.

3.3. Effect of Clorox concentrations and soaking periods on contamination percentage of surface sterilization for Gardenia explants

Data in Table (3) also show that clorox caused a decrease in contamination percentage of Gardenia. This was true between the different concentrations of clorox used and also when compared with the lowest concentration.

On the other hand, the data indicated that increasing the time of immersing the explants decreased the contamination percentage of. While, the best time achieved for free contaminated explants was $30 \mathrm{~min}$.

For the interaction, the results showed that the highest percentage of free contaminated explants were achieved at $30 \%$ clorox for 25 , while the lowest value of free contamination explants was found at $20 \%$ clorox for $15 \mathrm{~min}$.

For the interaction between clorox concentrations and soaking period, data in Tables (1,2 and 3 ) indicated that the best percentage of explant survival and contamination free explants were $(100.0$ and $100.0 \%)$ were observed when explants immersed for $25 \mathrm{~min}$ in $30 \%$ clorox. Obtained results showed that the lowest mortality percentage was that contained 30\% Clorox for 25 $\min (0.00 \%)$.

Table (3): Effect of Clorox concentrations and soaking periods on contamination percentage of surface sterilization for gardenia explants.

\begin{tabular}{|c|c|c|c|c|c|}
\hline $\begin{array}{c}\text { Min } \\
\text { Clorex }\end{array}$ & 15 & 20 & 25 & 30 & $\begin{array}{c}\text { Mean } \\
\text { (A) }\end{array}$ \\
\hline 20 & $\mathbf{5 5 . 5 5}$ & $\mathbf{4 4 . 4 4}$ & $\mathbf{4 4 . 4 4}$ & $\mathbf{3 3 . 3 3}$ & $\mathbf{4 4 . 4 4}$ \\
\hline 30 & $\mathbf{4 4 . 4 4}$ & $\mathbf{2 2 . 2 2}$ & $\mathbf{0 . 0 0}$ & $\mathbf{0 . 0 0}$ & $\mathbf{1 6 . 6 6}$ \\
\hline 40 & $\mathbf{2 2 . 2 2}$ & $\mathbf{0 . 0 0}$ & $\mathbf{1 1 . 1 1}$ & $\mathbf{0 . 0 0}$ & $\mathbf{8 . 3 3}$ \\
\hline Mean(B) & $\mathbf{4 0 . 7 4}$ & $\mathbf{2 2 . 2 2}$ & $\mathbf{1 8 . 2 2}$ & $\mathbf{1 1 . 1 1}$ & \\
\hline L.S.D at 5\% & $\mathbf{A}=11.43$ & $\mathbf{B}=13.20$ & $\mathrm{~A}^{*} \mathrm{~B}=\mathbf{2 2 . 8 7}$ & \\
\end{tabular}

\subsection{Effect of different concentrations of NAA on the establishment stage of Gardenia}

The results in Table (4) indicated that the best NAA concentrations were 2.0 and $4.0 \mathrm{mg} / \mathrm{l}$. The results showed quite clearly that the highest shoot length was 3.33 and $3.66 \mathrm{~cm}$ at 2.0 and 4.0 mg/l NAA, respectively. Also, the same concentrations of NAA showed the highest value of the number of leaves (7.66 and 8.33). However, the explants cultured on hormone free MSmedium (control) gave the shortest shootlet length 
$(0.44 \mathrm{~cm})$ and the lowest number of leaves $(4.33$ leaves).

These results are in line with others obtained with different species like Gerbera jamesonii (Aswath \& Choudhary, 2002 and Kumar et al., 2004). On the other hand, MS medium proved to be superior to B5 medium (Chikhale et al., 2004).

Table (4): Effect of different concentrations of NAA(mg/l )on the establishment stage of Gardenia jasminoides .

\begin{tabular}{|c|c|l|}
\hline NAA(mg/l) & Shoot Length cm & No. of leaves \\
\hline 0.0 & 0.44 & 4.33 \\
1.0 & 1.83 & 5.33 \\
2.0 & 3.33 & 7.66 \\
4.0 & 3.66 & 8.33 \\
\hline L.S.D at 5\% & 0.56 & 0.40 \\
\hline
\end{tabular}

\subsection{Effect of different concentrations of BA} and subculturing on the number of shoots for multiplication stage of Gardenia

For the number of shoots, the data calculated in Table (5) show that BA concentrations induced an increase in the number of shoots when compared with the control in each case. However, there were no significant differences in the number of shoots in the two higher levels of BA (4.0 and $5.0 \mathrm{mg} / \mathrm{l})$.

Concerning the effect of repeating the subculture, and regardless of the effect of various BA, it was evident that repeating subculture increased significantly number of shoots.

Regarding the interaction between BA and number of subculture, after three subcultures, the shoots were cultured on MS-medium supplemented with $4 \mathrm{mg} / \mathrm{l}$ BA produced the highest number of shoots. While the shoots in the first subculture on free hormone MS medium (control) did not produce any shoots.
On the other hand, BA at $0.5 \mathrm{mg} / \mathrm{l}$ was superior to $1.0,2.0$ or $4.0 \mathrm{mg} / \mathrm{l}$ when compared to the explants from the leaves of Gerbera (El-Shamy et al., 2009).

3.6. Effect of different concentrations of BA and subculturing on shoot length for multiplication stage of Gardenia

For the shoot length, data in Table (6) showed that raising the concentration of $\mathrm{BA}$ resulted in a significant decrease in shoot length $(8.67 \mathrm{~cm}$ control treatment). While the lowest value of shoot length $(4.67 \mathrm{~cm})$ was recorded with $5.0 \mathrm{mg} / \mathrm{l}$ BA.

For the effect of repeating the subculture on shoot elongation, it was found that elongation occurred and increased positively as time elapsed.

The interaction between the effect of BA and repeating the subculture, the elongation showed that $0.0 \mathrm{mg} / \mathrm{l} \mathrm{BA}$ at the third month, the longest shoots $(8.67 \mathrm{~cm})$ were obtained. Also, there were significant differences in shoot length between the different concentrations of BA and repeating the subculture.

3.7. Effect of different concentrations of $\mathbf{B A}$ and subculturing on the number of leaves for multiplication stage of gardenia

Results for the number of leaves presented in Table (7) showed that BA decreased the number of leaves probably due to a decrease in stem elongation and in the number of internodes. Thus, it was found that the highest the number of leaves was obtained and maintained at zero-level BA (16.57) when compared to the higher BA concentrations $(0.5,1,2,3,4$ and $5 \mathrm{mg} / \mathrm{l})$.

Concerning the number of leaves, data exhibited in Table (5) indicate that there were continuous additive decreases in the number of leaves due to the increase repeating the subculture. They were decreased as a result of repeating the subculture.

Table (5): Effect of different concentrations of BA and subculturing on the number of shoots for the multiplication stage of gardenia.

\begin{tabular}{|c|c|c|c|c|}
\hline BA mg/l & Subculture 1 & Subculture 2 & Subculture 3 & Mean(A) \\
\hline 0.0 & 1.00 & 3.33 & 6.66 & 3.56 \\
0.5 & 2.66 & 5.66 & 9.33 & 5.88 \\
1.0 & 3.66 & 7.66 & 10.66 & 7.33 \\
2.0 & 4.66 & 8.66 & 11.33 & 8.22 \\
3.0 & 5.33 & 9.33 & 11.66 & 8.77 \\
4.0 & 7.66 & 10.33 & 13.33 & 10.44 \\
5.0 & 8.00 & 10.66 & 13.66 & 10.77 \\
\hline Mean(B) & 4.71 & 7.95 & 10.95 & \\
\hline L.S.D at 5\% & $\mathbf{A = 0 . 5 2}$ & $\mathrm{B}=\mathbf{0 . 3 4}$ & $\mathrm{A}^{*} \mathrm{~B}=\mathbf{0 . 9 0}$ & \\
\end{tabular}


Table (6): Effect of different concentrations of BA and subculturing on shoot length for the multiplication stage of gardenia.

\begin{tabular}{|c|c|c|c|c|}
\hline BAmg/l & Subculture 1 & Subculture 2 & Subculture 3 & Mean(A) \\
\hline 0.0 & 4.16 & 5.83 & $\mathbf{8 . 6 6}$ & 6.28 \\
0.5 & 3.83 & 5.16 & 6.50 & 5.17 \\
1.0 & 3.83 & 5.00 & 6.16 & 5.00 \\
2.0 & 3.66 & 4.83 & 5.83 & 4.77 \\
3.0 & 3.50 & 4.66 & 5.66 & 4.61 \\
4.0 & 3.33 & 4.33 & 4.83 & 4.18 \\
5.0 & 3.16 & 3.83 & 4.66 & 3.88 \\
& & & & \\
\hline Mean(B) & 3.64 & $\mathbf{4 . 8 1}$ & $\mathbf{6 . 0 7}$ & \\
\hline
\end{tabular}

Table (7): Effect of different concentrations of $\mathrm{BA}$ and subculturing on the number of leaves for the multiplication stage of gardenia.

\begin{tabular}{|c|c|c|c|c|}
\hline BAmg/l & Subculture 1 & Subculture 2 & Subculture 3 & Mean(A) \\
\hline 0.0 & 11.66 & 17.00 & 21.00 & 16.57 \\
0.5 & 10.33 & 15.00 & 17.66 & 14.33 \\
1.0 & 9.66 & 12.00 & 16.00 & 12.78 \\
2.0 & 8.66 & 11.66 & 14.33 & 11.56 \\
3.0 & 7.00 & 10.00 & 12.33 & 9.78 \\
4.0 & 6.66 & 9.00 & 11.00 & 8.89 \\
5.0 & 6.00 & 9.00 & 9.66 & 8.22 \\
\hline Mean(B) & 8.57 & 12.048 & 14.57 & \\
\hline
\end{tabular}

For the interaction between the effect of BA and repeating the subculture on the number of leaves, the results showed that the number of leaves started to decrease from the first subculture and was more or less stable until the third subculture. Higher number of leaves was recorded at the third subculture (21) and the control treatment.

3.8. Effect of different concentrations of IBA and activated charcoal on shoot length for rooting stage of Gardenia

The results presented in Table (8) show that at the different concentrations of IBA, the longest shootlet $(11.33 \mathrm{~cm})$ was produced when MS medium contained $3.0 \mathrm{mg} / \mathrm{l} \mathrm{IBA}$. But the shortest shootlet length $(7.92 \mathrm{~cm})$ was recorded when the shoots were cultured on free hormone MS medium (control).

For activated charcoal, the highest shootlet length $(10.75 \mathrm{~cm})$ was formed when MS medium contained activated charcoal, while the shortest value of shootlet length $(9.25 \mathrm{~cm})$ was formed at MS medium without activated charcoal.

Also the results exhibited in Table (8) showed that MS medium containing $3.0 \mathrm{mg} / \mathrm{l}$ IBA with activated charcoal caused an increase in shootlet length $(12.17 \mathrm{~cm})$. This was true between the different concentrations of IBA with activated charcoal and also when compared with the zerolevel control.

3.9. Effect of different concentrations of IBA and activated charcoal on the number of leaves for rooting stage of Gardenia

Regarding IBA addition, data in Table (9) revealed that after rooting stage, the mean number of leaves was 25.17 at $3.0 \mathrm{mg} / 1 \mathrm{IBA}$ which was highly significant when compared with $0.0 \mathrm{mg} / \mathrm{l}$ IBA.

Activated charcoal was added in a separate rooting stage experiment with IBA at the same concentration used previously in order to improve the state of shootlets. As expected, improvement was observed in developing shootlets with respect to colour and the number of leaves.

Data of the interaction between IBA and activated charcoal showed quite clearly that the highest number of leaves (27.33) was formed at $3.0 \mathrm{mg} / 1 \mathrm{IBA}$ plus activated charcoal.

3.10. Effect of different concentrations of IBA and activated charcoal on the number of roots for rooting stage of gardenia

Data in Table (10) revealed that supplementation of MS medium with activated charcoal and IBA at 0.0, 1.0, 3.0 and $5.0 \mathrm{mg} / \mathrm{l}$ increased significantly the number of roots. IBA at $5.0 \mathrm{mg} / \mathrm{l}$ showed the highest 
Table (8): Effect of different concentrations of IBA and activated charcoal on shoot length for rooting stage of Gardenia.

\begin{tabular}{|c|c|c|c|}
\hline IBAml/l & With AC & Without AC & Mean(A) \\
\hline 0.0 & $\mathbf{8 . 6 6}$ & 7.16 & 7.92 \\
1.0 & 10.33 & 9.16 & 9.75 \\
3.0 & 12.16 & 10.50 & 11.33 \\
5.0 & 11.83 & 10.16 & 11.00 \\
\hline Mean(B) & 10.75 & 9.25 & \\
\hline \\
L.S.D at 5\% A=0.500 B=0.354 A*B=0.707
\end{tabular}

Table (9): Effect of different concentrations of IBA and activated charcoal on the number of leaves for rooting stage of Gardenia.

\begin{tabular}{|c|c|c|c|}
\hline IBAml/l & With AC & Without AC & Mean(A) \\
\hline 0.0 & 22.33 & 18.66 & 20.50 \\
1.0 & 23.66 & 19.33 & 21.5 \\
3.0 & 27.33 & 23.00 & 25.17 \\
5.0 & 25.00 & 22.23 & 23.67 \\
\hline Mean(B) & 24.58 & 20.83 & \\
\hline
\end{tabular}

L.S.D at 5\% $\quad A=1.060 \quad B=0.749 \quad A * B=1.499$

Table (10): Effect of different concentrations of IBA and activated charcoal on root length for rooting stage of Gardenia.

\begin{tabular}{|c|c|c|c|}
\hline IBAml/I & With AC & Without AC & Mean(A) \\
\hline 0.0 & 3.33 & 0.00 & 1.67 \\
1.0 & 4.50 & 0.00 & 2.25 \\
3.0 & 6.66 & 3.16 & 4.92 \\
5.0 & 10.00 & 3.83 & 6.92 \\
\hline Mean(B) & 6.12 & 1.75 & \\
\hline L.S.D at 5\% A=0.395 B=0.279 A*B=0.558 &
\end{tabular}

number of roots (12.83).

The addition of activated charcoal caused an increase in the number of roots of Gardenia plantlets as compared with the zero-level (control). The highest number of roots was found when activated charcoal was used.

The interaction between the different concentrations of IBA and activated charcoal was in general, significant in increasing the number of gardenia roots. The best medium was MS medium containing $5.0 \mathrm{mg} / \mathrm{l}$ IBA (16.33), with activated charcoal which led to the greatest number of shoots.

These results are in line with Amo-Marco and Ibanez (1997) on Limonium advanillesii and Matsumato et al. (1998) on hybrid Statice var. "Blue Symphonet".

3.11. Effect of different concentrations of IBA and activated charcoal on root length for rooting stage of Gardenia

Data in Table (11) revealed that the shoots Cultured on MS medium supplemented with 5 $\mathrm{mg} / \mathrm{l} \mathrm{IBA}$ produced the longest roots $(6.92 \mathrm{~cm})$. But, the shoots cultured on free hormone MS medium gave the shortest roots $(1.67 \mathrm{~cm})$.

For activated charcoal, the highest root length was observed in MS medium supplemented with activated charcoal $(6.13 \mathrm{~cm})$ compared to the medium without activated charcoal which gave $1.75 \mathrm{~cm}$.

Regarding the interaction between IBA concentrations and activated charcoal, shoots cultured on MS medium containing $5 \mathrm{mg} / \mathrm{l} \mathrm{BA}$ and activated charcoal produced the longest roots $(10 \mathrm{~cm})$. While, the shoots on free hormone MS medium (control) gave no roots.

3.12. Effect of different concentrations of peatmoss and sand on acclimatization stage of Gardenia jasminoides.

All rooted shoots were acclimatized on peatmoss and sand. The survival of plantlet after one month was calculated and gained $100 \%$ percentage (Table 12). 
Table (11): Effect of different concentrations of IBA and activated charcoal on the number of roots for rooting stage of Gardenia.

\begin{tabular}{|c|c|c|c|}
\hline IBAml/I & With AC & Without AC & Mean(A) \\
\hline 0.0 & 2.66 & 0.00 & 1.33 \\
1.0 & 4.66 & 0.00 & 2.33 \\
3.0 & 9.33 & 0.33 & 7.83 \\
5.0 & 16.33 & 9.33 & 12.83 \\
\hline Mean(B) & $\mathbf{8 . 2 5}$ & 3.92 & \\
\hline L.S.D at 5\% & $\mathbf{A = 0 . 8 6 5}$ & $\mathbf{B}=\mathbf{0 . 6 1 2} \quad \mathrm{A} * \mathrm{~B}=1.224$ &
\end{tabular}

Table (12): Effect of different concentrations of peatmoss and sand on acclimatization stage of Gardenia jasminoides .

\begin{tabular}{|c|c|c|}
\hline Peatmoss: sand(v/v) & Shootlet length & No.of leaves \\
\hline $1: 0$ & 14.66 & 14.66 \\
$1: 1$ & 12.66 & 11.66 \\
$1: 2$ & 15.33 & 17.00 \\
\hline L.S.D at 5\% & n.s & n.s \\
\hline
\end{tabular}

\section{REFERENCES}

Abdullah G.R., Al-Khateeb A.A. and Serage M. (2003). Effect of different concentrations of growth regulators on Gardenia jasminoides cv. Veitchii micropropagation by tissue culture technique. Sultan Qaboos University J. for Scientific Res. Agric. Sci., 8(1):35-40.

Amo-marco J. B. and Ibanez Z. M. R. (1997). Micropropagation of Limonium cavanillesii Erben, a threatened static from inflorescence stem. Plant Growth Reg., 24: 49-54.

Aswath C. and Choudhary M.L. (2002a). Mass propagation of gerbera (Gerbera jamesonii) through shoot culture. Indian Journal of Horticulture, 59(1): 95-99.

Chikhale N.J., Bokey A.H. and Rai M.K. (2004). Micropropagation studies in gerbera (Gerbera jamesonii). Recent trends in biotechnology, 171-176.

Dumanois C., Godin B. and Bigot C. (1984). In vitro vegetative propagation of Gardenia jasminoides Ellis. J. of Plant Physiology, 116(5):389-407.

Economou A.S. and Spanoudaki M.J. (1986). The influence of cytokinins and gibberellic acid on Gardenia tissue cultures. Scientia Hort., 29(1/2):155-161.

El-Shamy M.A., Abdel-Sattar M.M., El-Fouly Amal S.A. (2009). Studies on Gerbera jamesonii Bolus cv. aurantiaca, Under micropropagation condition. J. Agric. Sci. Mansoura Univ., 34 (3) 1939-1951.

George P.S., Ravishankar G.A. and Venkataraman L.V. (1993). Clonal multiplication of
Gardenia jasminoides Ellis through axillary bud culture. Plant Cell Reports, 13(1):59-62.

Hosni A. M. (2001). Increasing the potential of in vitro propagation of Strelitzia reginae Ait. by controlling oxidative browning of explant tissues. Arab Universities Journal of Agricultural Sciences. 9(2): 839-852.

Kumar S., Kanwar J.K. and Sharma D.R. (2004). In vitro regeneration of Gerbera jamesonii Bolus from leaf and petiole explants. Journal of Plant Biochemistry and Biotechnology, 13(1): 73-75.

Matsumato T., Nako Y., Takahashi C. and Sakai A. (1998). Induction of in vitro culture masses of shoot primordial of hybrid static and its cryopreservation by vitrification. HortScience, 32 (2): 359369.

Minas G.J. (2007). A rapid protocol for in vitro micropropagation of three types of gardenia (Gardenia spp. Ellis) for quality produce flowering pot-plants. Acta Hort., 75(5):81-86.

Mir F.A., Yadav A.S., Bajaj A., Sharma A.K., Rai A., Lone S.A. and Raghuwanshi D.K. (2010). Organogenesis from leaf and internode explants of Gardenia gummifera Linn. an endangered medicinal plant. Asian J. of Experimental Sci., 24(1):unpaginated.

Mir F.A., Yadav A.S., Sharma A.K., Raghuwanshi D.K., Rai A.K. and Lone S.A. (2009). In vitro protocol for conservation of Gardenia gummifera Linn an endangered medicinal plant. Flora and 
Fauna, 15(2):219-223.

Pontikis C.A. (1983). In vitro propagation of Gardenia jasminoides. Plant Propagator, 29(3):13-14.

Shen H.J. (1990). Studies of the peroxidase isoenzyme pattern during morphogenesis in Gardenia jasminoides and
Dendranthema morifolium cv. Xia Ju. Acta Horti. Sinica, 17(1):65-70. Snedecor G.W. and Cochran W.G. (1989). OneWay Classification, analysis of variance. In: Statistical Methods (8th Ed.). Iow State Univ. Press, Ames, Iowa, U.S.A., ch. 12, pp. 217- 236.

\footnotetext{
اكثار نبات الجاردينيا (Gardenia jasminoides) بواسطة نثنيات زراعة الأنسجة

عزة محم سعيدعرفة ـ صفية حمدى الحنفى - ممدوح أحمد إبراهيم الثامى*-نثوى عبد القادر نمره*

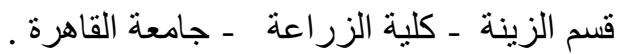

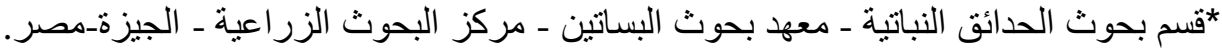

ملخص
}

أجريت هذه الدر اسة فى خلال الفترة من سنة 2010- 2012 في معمل زر اعة الأنسجة التابع لمعهد بحوث البساتين -

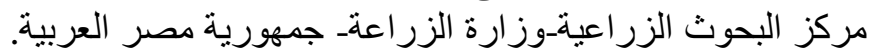
يهذف هذا البحث إلى معرفة أنسب المعاملات لإكثار نبات الجاردينيا عن طريق زر اعة الأنسجة وذلك لوضع بروتوكول للإكثار الدقيق لهذا النبات.

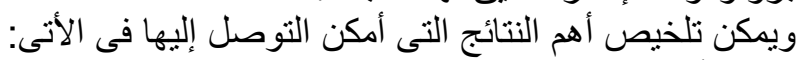

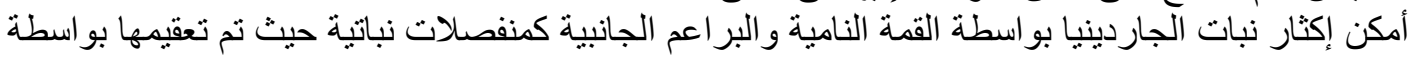

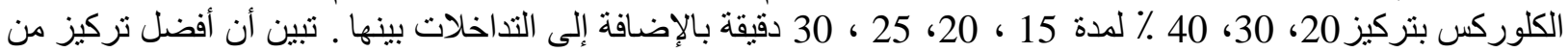

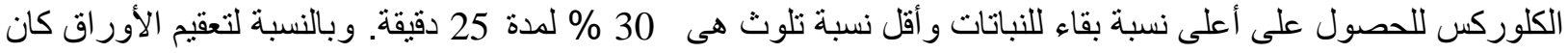
20 30 كدة 15 دقيقة.

أستخدمت فى مرحلة التأسيس بيئة مور انثيجى وسكوج المضاف إليها نفتالين حمض الخليك بتركيز صفر ، 1.0، 2.0،

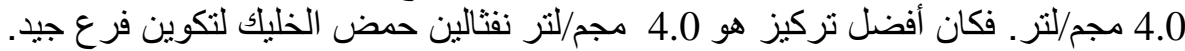

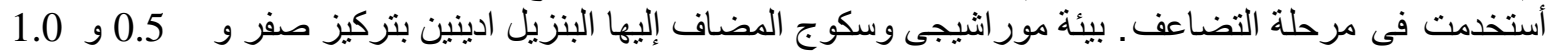

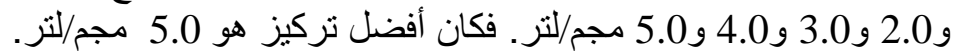

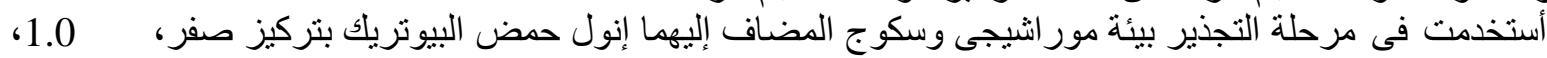

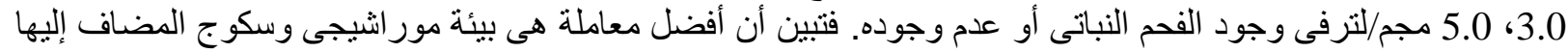

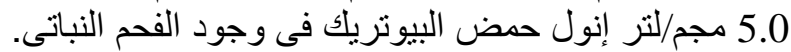

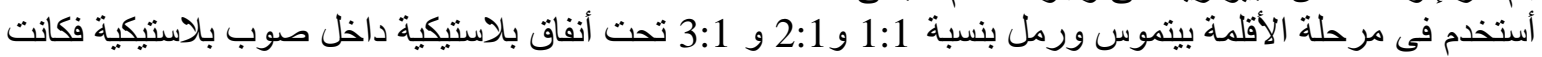
نسبة نجاحها 100\% في ملئ كل المعاملات.

المجلة العلمية لكلية الزراعة - جامعة القاهرة - المجلد (64) العدد الثالث (يوليو 2013): 303- 310. 